\title{
THE CLINICO-MORPHOLOGICAL CHARACTERISTICS OF ANOMALIES IN THE LARGE INTESTINE IN CHILDREN
}

\author{
Bodnar G. B., Bodnar B. M.
}

\section{INTRODUCTION}

An increase of the case rate of congenital anomalies in the large intestine (CALI) has been marked among the pathology of the gastrointestinal tract in children in recent years. These particular anomalies, despite the differences in the localization of changes in the large intestine (LI), are united by a characteristic clinical sing - the presence of chronic constipation. Chronic constipation organic origin (CCOO) in children due to CALI: dolihosigmoid, dolichocolon, megadolichocolon and others remain one of the most serious problems in modern gastroenterology, since they are characterized by an undulating course, late diagnosis, the development of local and systemic complications, an unfavorable prognosis and invalidism.

Children suffering from this serious chronic pathology as a rule have a deficit of the body weight with a decrease of the subcutaneous fat and diminished tissue a stunt is often observed in them. Disturbances of the nutritive in case CALI are stipulated by a number of case: the development of intestinal dysbacteriosis, reduction of the absorptive surface of the mucous membrane due to an inflammatory and/or atrophic process, absence of appetite or refusal of food intake view of arising pains in the abdomen after meals, meteorism; and increase energy consumption in connection with the development of the phenomena of intoxication.

Diseases of the large intestine (LI) occupy a significant place in the structure of chronic diseases of the digestive system ${ }^{1,2}$. Along with functional pathology, conditions caused by developmental abnormalities and the position of the LI cause concern, among which the most frequent one is dolichosigmoid (45-50\%) that indirectly creates the basis for the development of chronic inflammatory and functional diseases not only of the LI, but of the entire digestive system ${ }^{3}$.

${ }^{1}$ Белоусова О. Ю., Казарян Л. В. Функціональні гастроінтестинальні розлади в дітей раннього віку: лікувати, спостерігати чи корегувати? Здоров'я дитини. 2020. T. 15. № 1. C. 24-25. DOI: 10.22141/2224-0551.15.1.2020.196754.

Боднар Г.Б., Боднар Б.М. Принцип FP в корекції дисинхронозу моторноевакуаторної функції кишечника в дітей. Здоров'я дитини. Т. 14, № 1. 2019. C. 48. DOI: 10.22141/2224-0551.14.0.2019.165519.

3 Николаева С.В., Горелов А.В. Лечение и профилактика функциональных запоров у детей. Трудный пациент. 2019. Т. 17. № 1-2. С. 37. 
A characteristic radiographic image of dolichosigmoid is an elongated sigmoid colon, which forms from 2 to 5 additional loops that occupy the entire hypogastric region ${ }^{4}$. In some children constipation occurs as early as the first month of life, usually after the introduction of baby food, rarely at a later age, but normally not later than starting school. According to some authors $^{5}$, in $15 \%$ of cases dolichosigmoid can occur in perfectly healthy children and have no clinical symptoms, often being diagnosed accidentally, which allows considering elongation of the LI as a variation of a norm in such cases. However, in most children dolichosigmoid leads to functional and organic disorders of the lower $\mathrm{LI}^{6}$. It is accompanied by a complex of sufficiently expressed clinical symptoms, including intractable chronic constipation (CC), abdominal pain and signs of chronic intoxication.

Depending on the severity of clinical and radiological symptoms, we distinguish between compensated, subcompensated and decompensated stages of congenital elongation of the sigmoid colon. During the initial stage constipations occur sporadically. Once in a rare while the patient experiences short-term abdominal pains (primarily in the left iliac region) and tympanites. The child's condition improves after defecation. The subcompensated form of dolichosigmoid is characterized by a more intractable constipation. Children may not have an independent stool for 23 days. Abdominal pain and tympanites are very common. A hard-sigmoid colon filled with fecal matter is palpable in the left lower abdomen. The most intractable constipations develop at the stage of decompensation. In such cases, children have a very weak urge to defecate, bowel evacuation is only possible after the administration of a cleansing enema. Children suffer from a severe abdominal pain, vomiting. Many develop encopresis dye to the decreased tone of the distended sigmoid colon and rectum.

Children with the decompensated course of CC demonstrate more pronounced signs of chronic intoxication: weakness, rapid fatigue, skin pallor, headache, periorbiotal cyanosis. At this stage of CC against the background of dolichosigmoid, there is a high risk of intestinal obstruction. That is, over time, compensatory mechanisms of LI decrease. Y.S. Zimmerman believes that dolichosigmoid causes constipation and constipation contributes to the development of dolichosigmoid, which creates a vicious circle as a result.

${ }^{4}$ Borowitz S.M., Cox D.J. Treatment of childhood constipation by primary care physicians: efficacy and predictors of outcome. Pediatrics. 2005. Vol.115, № 4. P:873. DOI: 10.1542 / peds.2004-0537.

Боднар Г.Б., Боднар Б.М. Принцип FP в корекції дисинхронозу моторноевакуаторної функції кишечника в дітей. Здоров’я дитини. 2019. Т. 14. № 1. C. 48-49. DOI: 10.22141/2224-0551.14.0.2019.165519.

${ }^{6}$ Risk factors for chronic constipation based on a general practice sample / N.J. Talley. Am J Gastroenterol. 2003. Vol. 98. № 5. P. 1107. DOI: 10.1111/j.15720241.2003.07465.x. 
A.I. Lenyushkin (1999) calls dolichosigmoid a "progenitor of pathology", a particular background for the development of clinical pathology. Therefore, CC against the background of dolichosigmoid disrupts the child's adaptation, significantly affecting the quality of life, and having an adverse effect on the growth and development of the child's body ${ }^{7}$.

\section{Material and methods}

The objective of the work is to study the specifics of tissue immunity and intestinal microbiocenosis, depending on the stages of $\mathrm{CC}$ due to the congenital elongation of the sigmoid colon (CESC) in children.

We examined 109 children with CC against the background of dolichosigmoid, who were taking in-patient treatment at pediatric surgery and gastroenterology departments of Chernivtsi City Clinical Children’s Hospital, alongside with 40 generally healthy children. CESC (dolichosigmoid) was diagnosed based on irrigographic examination, which was conducted for all children at admission in order to study anatomical and physiological condition of the LI.

Children with dolichosigmoid were divided into groups according to the stage of CC established on the basis of commonly-accepted criteria. Group 1 consisted of 39 children (35.8\%) with the compensated stage of CC, their stool frequency was once every 2-3 days (average stool retention was $2.5 \pm 0.5$ days); a characteristic clinical sign for patients in this group was the feeling of incomplete bowel evacuation (23 children (59.0\%)). Most patients (56.2\%) had tympanites and abdominal pain that would disappear in 7 (19.9\%) patients or increase in 12 (30.8\%) after defecation. Group 2 consisted of children with the subcompensated stage of CC against the background of dolichosigmoid (36 children (33.0\%)). For children in the second group a 35-day stool retention (an average of $4.3 \pm 0.6$ days) was common, at that the necessity to take laxatives or have a cleansing enema was registered in $47.2 \%$ of patients with this stage of CC. Patients in this group suffered from: abdominal pain (88.9\%), tympanites (94.4\%), painful defecation (41.7\%), and extraintestinal signs of constipation (27.8\%). The most intractable constipation was observed in children of group 3 with the decompensated stage of CC (34 children (31.2\%)). Most patients from this group had a very weak urge to defecate, bowel evacuation occurred only after a cleansing enema in $91.2 \%$ of patients. Children suffered from a severe abdominal pain (88.2\%), vomiting (61.8\%), 18 children (52.9\%) were diagnosed with encopresis, often showing signs of chronic intoxication (weakness, rapid fatigue, pallor, headache).

7 Боднар Г.Б., Боднар Б.М. Принцип FP в корекції дисинхронозу моторноевакуаторної функції кишечника в дітей. Здоров'я дитини. 2019. Т. 14. № 1 . C. 48-52. DOI: 10.22141/2224-0551.14.0.2019.165519. 
The condition of microbiocenosis of the LI was determined as a result of microbiological examination of stool culture in differential diagnostic mediums under the certain incubation conditions with further microscopic evaluation. The quantitative composition LI microflora in $1 \mathrm{~g}$ of faeces was determined based on the number of colonies, which had grown in the corresponding nutrient media, and expressed in colony-forming units (CFU). The severity of intestinal dysbiosis was determined using the classification suggested by I.B. Kuvaeva and K.S. Ladodo (1991). The received data were compared to the results of microbial landscape in the LI lumen of the control group.

Coprological examination of faeces that included finding the $\mathrm{pH}$ value in the LI environment was conducted upon admission to hospital pursuant to a standard procedure, with stool $\mathrm{pH}$ being determined using a $\mathrm{pH}$ meter. Also, the concentration of secretory immunoglobulin A (sIgA) in coprofiltrates was studied in all children to determine the condition of the LI tissue immunity by means of radial immunodiffusion in the gel using the method of Manchini.

Statistical processing of the received results was performed using the commonly-accepted methods of variation statistics. The standard PC "Statistica 5.0" software package for Windows XP was used for that. Mean value of each indicator was evaluated (M), alongside with mean errors (m). Student's t-test $(\mathrm{t})$ was used for making comparisons and finding the difference significance levels in samples with quantitative indicators. The difference between the compared values was considered significant at $\mathrm{p}<0.05$.

\section{Results of research and their discussion}

Microbiological examination of faeces in all children with CC against the background of CESC showed that LI dysbiosis was characteristic of those patients. Thus, we were able to diagnose the normal composition of the LI microflora in only 6 ( $5.5 \pm 1.3 \%$ ) children, however it should be noted that these patients had CESC with the compensated and subcompensated stages of CC.

Microbial composition disorder was found in the remaining patients 103 children (94.5 $\pm 3.3 \%)$, including all the children with the decompensated CC (34 (100\%)) (Table 1).

The microflora of the LI contents in children with CESC (dolichosigmoid) was characterized by the elimination of enterococci from the biotope; contamination of LI lumen with pathogenic (enterotoxigenic Escherichia) and potentially pathogenic (bacteria of the Enterobacter, Citrobacter, Proteus geni) enterobacteria, hay bacillus and yeast-like Candida fungi.

We have found that children with dolichosigmoid have a significant deficiency of the most physiologically useful autochthonous obligate anaerobic bifidobacteria and lactobacteria in the lumen of the LI depending on the progression of the pathological process, increase in the population 
level, coefficient of quantitative dominance and quantitative polydominance of the potentially pathogenic bacteria of the Bacteroides, Peptococcus, Staphylococcus geni.

The above microorganisms contaminating the lumen of LI in children with dolichosigmoid persist in a moderate and high population levels and have a moderate coefficient of quantitative dominance and quantitative polydominance.

Table 1

Microbiological Examination of the Content of the Large Intestine

Lumen in Children with Chronic Constipation Having Congenital Large Colon Abnormalities

\begin{tabular}{|c|c|c|c|c|c|c|c|c|}
\hline \multirow[t]{2}{*}{$\begin{array}{l}\text { Micro- } \\
\text { biocenosis } \\
\text { indicators }\end{array}$} & \multicolumn{2}{|c|}{$\begin{array}{l}\text { Children } \\
\text { with } \\
\text { compensat } \\
\text { ed } \\
\text { constipatio } \\
\text { n }(\mathbf{n}=39)\end{array}$} & \multicolumn{2}{|c|}{$\begin{array}{l}\text { Children } \\
\text { with } \\
\text { subcompen } \\
\text { sated } \\
\text { constipatio } \\
\text { n }(n=36)\end{array}$} & \multicolumn{2}{|c|}{$\begin{array}{l}\text { Children } \\
\text { with } \\
\text { decompensa } \\
\text { ted } \\
\text { constipation } \\
(\mathrm{n}=34)\end{array}$} & \multicolumn{2}{|c|}{$\begin{array}{l}\text { Generally } \\
\text { healthy } \\
\text { children } \\
(n=40)\end{array}$} \\
\hline & abs. & $\%$ & abs. & $\%$ & abs. & $\%$ & abs. & $\%$ \\
\hline Normal flora & 3 & 10.3 & 3 & 8.3 & 0 & - & 29 & 72.5 \\
\hline $\begin{array}{l}\text { Stage } 1 \\
\text { dysbacteriosis }\end{array}$ & 18 & 46.2 & 12 & 33.3 & 8 & 23.5 & 7 & 17.5 \\
\hline $\begin{array}{l}\text { Stage } 2 \\
\text { dysbacteriosis }\end{array}$ & 13 & 33.3 & 13 & 36.1 & 11 & 32.4 & 4 & 10.0 \\
\hline $\begin{array}{l}\text { Stage } 3 \\
\text { dysbacteriosis }\end{array}$ & 5 & 12.8 & 7 & 19.4 & 12 & 35.3 & 0 & - \\
\hline $\begin{array}{l}\text { Stage } 4 \\
\text { dysbacteriosis }\end{array}$ & 0 & 0 & 1 & 2.8 & 3 & 5.9 & 0 & - \\
\hline
\end{tabular}

While studying tissue immunity indicators we have found a decrease in the level of secretory immunoglobulin A concentration in coprofiltrates of children with CESC (Table 2). The analysis of secretory immunoglobulin A levels in coprofiltrates of the examined children showed a significant decrease in the concentration of sIgA - 1.3 times lower in patients with CESC $(p<0.05)$ as compared to children from the control group. The level of secretory immunoglobulin concentration in children with CC against the background of CESC was dependent on the stage. In children with the compensated stage of CC, the level of secretory immunoglobulin A was, on average, lower by $1.7 \%$ as compared to the children in the control group, but it was $8.5 \%$ higher than in children with the decompensated stage of CC. 
Table 2

Results of Secretory Immunoglobulin a Coprofiltrates Test in Patients with Chronic Constipation Having

Congenital Large Colon Abnormalities

\begin{tabular}{|c|c|c|c|c|}
\hline Indicator & $\begin{array}{c}\text { Children } \\
\text { with the } \\
\text { compensated } \\
\text { constipation } \\
(\mathrm{n}=39)\end{array}$ & $\begin{array}{c}\text { Children } \\
\text { with the } \\
\text { subcom- } \\
\text { pensated } \\
\text { constipation } \\
(\mathbf{n}=\mathbf{3 6})\end{array}$ & $\begin{array}{c}\text { Children } \\
\text { with the } \\
\text { decom- } \\
\text { pensated } \\
\text { constipation } \\
(\mathbf{n}=\mathbf{3 4})\end{array}$ & $\begin{array}{c}\text { Generally } \\
\text { healthy } \\
\text { children } \\
(\mathbf{n}=\mathbf{4 0 )}\end{array}$ \\
\hline sIgA, $\mathrm{mg} / \mathrm{l}$ & $117,0 \pm 12.8^{*}$ & $110.7 \pm 10.9^{*}$ & $102.6 \pm 50.0^{*}$ & $129.3 \pm 10.7$ \\
\hline
\end{tabular}

Note: $*$ - difference from the control group is statistically significant $(\mathrm{p}<0.05)$

$\mathrm{pH}$ value of the LI environment is one of the main values in a coprological examination of faeces. The analysis of the $\mathrm{pH}$ value of coprofiltrates in children with CESC showed a significant shift in the alkaline direction (7.78) as compared to the values of children in the control group (Table 3) (6.21).

Table 3

Faeces pH Level in Patients with Chronic Constipation Having Congenital Large Colon Abnormalities

\begin{tabular}{|c|c|c|c|c|}
\hline $\begin{array}{c}\text { Indi- } \\
\text { cator }\end{array}$ & $\begin{array}{c}\text { Children with } \\
\text { compensated } \\
\text { constipation } \\
\text { (n= 39) }\end{array}$ & $\begin{array}{c}\text { Children with } \\
\text { subcompensated } \\
\text { constipation } \\
\text { (n= 36) }\end{array}$ & $\begin{array}{c}\text { Children with } \\
\text { decompensate } \\
\text { d constipation } \\
\text { (n= 34) }\end{array}$ & $\begin{array}{c}\text { Generall } \\
\text { y healthy } \\
\text { children } \\
\text { (n= 40) }\end{array}$ \\
\hline $\mathrm{pH}$ & $7.2 \pm 0,2$ & $7.6 \pm 0.2^{* *}$ & $7.9 \pm 0.6^{*}$ & $6.8 \pm 1.1$ \\
\hline
\end{tabular}

Note: * - difference from the control group is statistically significant $(\mathrm{p}<0.05)$; ** - difference from the control group of children with the decompensated stage is significant $(\mathrm{p}<0.05)$

Faeces $\mathrm{pH}$ values of children from groups with the compensated, subcompensated, and decompensated stages of CC were significantly different from those of the control group $(\mathrm{p}<0.05)$. However, it should be noted that the average $\mathrm{pH}$ of faeces in children with the compensated stage was close to that of the control group ( $p>0.05)$.

Evaluation of the $\mathrm{pH}$ level of faeces, depending on the stage of CC, showed a shift in the $\mathrm{pH}$ level towards the alkaline direction in children with the sub- and decompensated stages by $7.6 \pm 0.2$ and $7.9 \pm 0.6$, respectively, indicating a tendency to boost fermentation and putrefaction processes in the LI among patients of these groups.

In the course of correlation analysis, it was revealed that the sIg A value largely depends on the level of indigenous flora. Thus, the correlation coefficient 
for bifidobacteria makes $r=+0.53$, for lactobacteria $r=+0.67$ with $p<0.05$, which showed direct dependence of sIg A levels on the level of indigenous flora. Furthermore, we have established a connection between the level of sIg A and the quantity of certain potentially pathogenic flora agents: for Escherichia coli $r=-0.21$, which presumes inverse dependence on the number of Escherichia coli. We have not found any correlation dependence on other microorganisms in our research. A decrease in bifidobacteria and lactobacteria causes the deficiency of secretory Ig A, which in turn causes an increase in the permeability of the epithelial barrier of the intestine, trophicity impairment of the LI wall tissues, significant changes in tissue immunity, the development of transient immunodeficiency, and launches the inflammatory process in the LI, which is one of the most significant risk factors for the development of CC decompensation against the background of CESC and the occurrence of complications. The revealed correlation relationship allowed assuming that the level of secretory immunoglobulin A in coprofiltrates of children can be indicative of dysbiotic changes in the bowels, i. e. this indicator may be an additional marker of dysbacteriosis and CC decompensation.

Therefore, finding stool $\mathrm{pH}$ and sIg A values in coprofiltrates using a non-invasive method of diagnosis makes it possible to assess the condition of tissue immunity and microbiocenosis of the bowels, and trace transformation of the compensated stage into the sub- and decompensated stages, which allows identifying the risk group as to the development of adverse effects of dolichosigmoid, taking measures to prevent the progression of the pathological process and the development of complications. These indicators can be used as additional diagnostic criteria with a detailed algorithm intended for doctors of different specialties to be subsequently developed for differential diagnostics of CC in children.

An important role in the complex chain of interconnected processes and numerous specialized systems to ensure the stability of the internal environment of the body belongs to the immune system, in close functional connection with which are the local non-specific body protection factors - lysozyme.

Lysozyme prevents free radical oxidation, participates in the regulation of immune and metabolic processes, alongside with antihistamine, antiantacid, antitoxic processes; it is a common element of the systems responsible for the membrane-stabilizing effect. In addition, lysozyme prevents penetration of foreign agents into the internal environment of the body by stimulating phagocytosis, it promotes antigen recognition, enhances the cooperative functions of T-lymphocytes populations, bacteriolytic and anti-adhesive properties of sIgA.

Finding lysozyme levels in various biological substrates belongs to the category of high sensitivity tests, reflecting the activity of inflammatory process and the status of the immunobiological response of the body, which 
allows using them as an additional criterion in diagnosing and forecasting the development of various diseases. Taking into consideration high sensitivity of lysozyme to changes in the functional status of the large intestine, we have studied their levels in coprofiltrates as immunological markers.

The levels of lysozyme tended to decrease in 77 (70.64 $\pm 4.36 \%)$ children, and to increase in 32 (29.36 $\pm 4.36 \%)$; we have not found a single case, where this indicator would reach the values of healthy children. In general, children with dolichosigmoid would typically show a decrease in the levels of lysozyme in coprofiltrates by 1.24 times as compared to the generally healthy children (Table 4).

Table 4

Mucosal Immunity Indicators (Lysozyme) in Children with Chronic

Constipation Due to the Congenital Elongation of the Large Intestine

\begin{tabular}{|c|c|c|}
\hline Indicator & Main group & Reference group \\
\hline Lysozyme, $\mathrm{mcg} / \mathrm{ml}$ & $1.01 \pm 0,01^{*}$ & $1.26 \pm 0.01$ \\
\hline
\end{tabular}

Note: $*$ - probable difference, $p<0.001$

Such a level of local protective factors in the coprofiltrate obviously reflects an increase in the inflammatory response in the colon of children with CC due to dolichosigmoid.

An equally important section of the work was dedicated to the evaluation of results of examination of fecal immunological markers depending on the stage of clinical course in children from the main group.

Lysozyme levels tended to increase and were likely $(p<0.05)$ to exceed the values of healthy children. Such a level of local protection factor in the coprofiltrate obviously reflects the absence or reduction of the inflammatory response in the colon (table 5).

Table 5

Characteristics of The Immunological Marker of the Functional Status of the Colon in Children with the Compensated Stage of Chronic Constipation Due to the Congenital Elongation of the Sigmoid Colon

\begin{tabular}{|c|c|c|}
\hline Indicators & $\begin{array}{c}\text { Children with the compen- } \\
\text { sated Stage }\end{array}$ & $\begin{array}{c}\text { Generally } \\
\text { healthy children }\end{array}$ \\
\hline Lysozyme, $\mathrm{mcg} / \mathrm{ml}$ & $1.31 \pm 0.02^{*}$ & $1.26 \pm 0.01$ \\
\hline
\end{tabular}

Note: * - probable difference, $\mathrm{p}<0.05$

Findings of the examination of immunological markers of the functional status of the colon in children with the subcompensated course of dolichosigmoid are shown in Table 6. 
Table 6

Characteristics of Immunological Markers of the Functional Status of the Large Intestine in Children with the Subcompensated Stage of Chronic Constipation Due to the Congenital Elongation of the Sigmoid Colon

\begin{tabular}{|c|c|c|}
\hline Indicators & $\begin{array}{c}\text { Children with the sub- } \\
\text { compensated course }\end{array}$ & $\begin{array}{c}\text { Generally healthy } \\
\text { children }\end{array}$ \\
\hline Lysozyme, $\mathrm{mcg} / \mathrm{ml}$ & $1.10 \pm 0.02^{*}$ & $1.26 \pm 0.01$ \\
\hline
\end{tabular}

Note: ${ }^{*}$ - probable difference, $\mathrm{p}<0.001$

The presented findings of the examination testify to the obvious change in the nonspecific (lysozyme) factors of body resistance in children with CC caused by dolichosigmoid as the pathological process progresses.

All patients (100.0\%) with the decompensated stage of dolichosigmoid have shown total decrease in immunological markers of the mucosal component status of the immune system (Table 7). Levels of coprofiltrate lysozyme were 1.3 times lower.

Table 7

Characteristics of Immunological Markers of the Functional Status of the Large Intestine in Children with the Decompensated Stage of Chronic Constipation Due to the Congenital Elongation of the Sigmoid Colon

\begin{tabular}{|c|c|c|}
\hline Indicators & $\begin{array}{c}\text { Children with the de- } \\
\text { compensated course }\end{array}$ & $\begin{array}{c}\text { Generally healthy } \\
\text { children }\end{array}$ \\
\hline Lysozyme, $\mathrm{mcg} / \mathrm{ml}$ & $0.94 \pm 0.01^{*}$ & $1.26 \pm 0.01$ \\
\hline
\end{tabular}

Note: $*$ - probable difference, $\mathrm{p}<0.001$

While analyzing the dynamics of immunological markers of the mucosal component status of the immune system in children with chronic organic constipation due to the congenital elongation of the sigmoid colon, we have found that the dynamics towards the reduction is typical of the sIgA levels as the pathological process progresses (Fig. 1).

Therefore, at the initial stages of chronic constipation caused by dolichosigmoid, with the preserved compensatory capacity of the body we can observe mobilization of the immune system, which is revealed through the increased levels of sIgA in coprofiltrates. As the pathological process progresses, the compensatory capacity decreases, and in that event, normalization of the sIgA levels, in our opinion, should be considered as a factor indicating the exhaustion of compensatory mechanisms. This is proven by further decline dynamics during the decompensated stage of the 
course, when values become critical in most cases decreasing by 2.6 times as compared to the values of the generally healthy children.
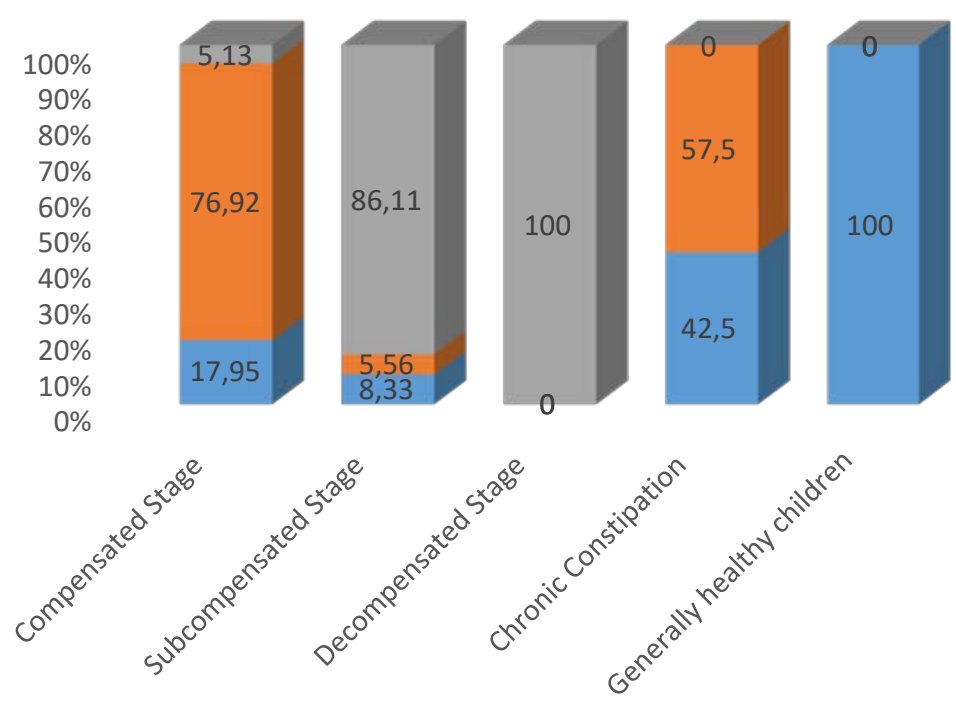

slgA level normal घelevated level slgA $\quad$ reduced level slgA

Fig. 1. The Dynamics of Levels of Secretory Immunoglobulin A in the Coprofiltrates of Children with the Progression of Chronic Constipation Due to the Congenital Elongation of the Sigmoid Colon

A similar trend can be observed in the dynamics of changes in lysozyme levels in coprofiltrates of children from the main group depending on the stage of the clinical course (Fig. 2).

While analyzing the findings, it's worth mentioning the fact that lysozyme levels, which would be close to the values of generally healthy children, have not been found in patients from the main group, which, in our opinion, may indicate that the line between compensatory and decompensatory capacity of the child's body is very subtle.

The findings testify to the development of secondary local immunity deficiency in children with CC due to dolichosigmoid as the pathological processes.

It can be assumed that insufficient formation of sIgA and lysozyme in the colon of children with CC due to the congenital elongation of the sigmoid colon, combined with the disruption of the parietal mucous layer, contributes to maintaining inflammatory changes in the colon, slowing down the 
motility, which, in turn, deepens the impairment of the digestive, buffer, protective functions of the paraepithelial layer of the colon and causes organic disorders in all layers of the large intestine.
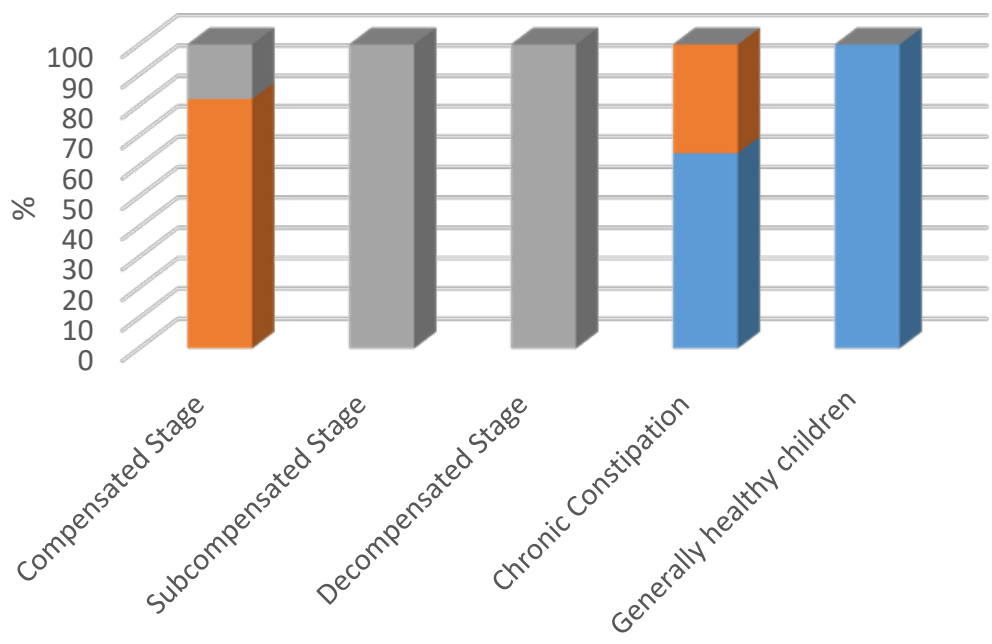

- Lysozyme Levels normal $\quad$ increased decrease level

Fig. 2. The Dynamics of Changes in Lysozyme Levels in Coprofiltrates of Children with the Progression of Chronic Constipation Due to the Congenital Elongation of the Sigmoid Colon

As a result of analyzing the findings we have received excellent indicators of the levels of fecal immunological markers of the functional state of the large intestine, depending on the presence of signs of nonspecific ulcerative colitis in children (Table 7).

Table 7

Indicators of the Mucosal Component of the Immune System in Children with Chronic Constipation Due to the Congenital Elongation of the Sigmoid Colon

\begin{tabular}{|c|c|c|}
\hline \multirow{2}{*}{ Indicators } & \multicolumn{2}{|c|}{ Children with dolichosigmoid } \\
\cline { 2 - 3 } & with signs of colitis & without signs of colitis \\
\hline sIgA, $\mathrm{mg} / \mathrm{l}$ & $101.9 \pm 6,98^{*}$ & $180.4 \pm 9.3$ \\
\hline Lysozyme, $\mathrm{mcg} / \mathrm{ml}$ & $0.98 \pm 0.04^{*}$ & $1.23 \pm 0.02$ \\
\hline
\end{tabular}

None: * - probable difference as compared to values of Subgroup V, p $<0.001$ 
The finding show that the decline in non-specific and specific resistance factors in children with CC due to the congenital elongation of the sigmoid colon enhances the development of such a serious complication as nonspecific non-ulcerative colitis, which significantly complicates the underlying disease and causes decompensation.

Therefore, finding sIgA and lysozyme levels in coprofiltrates of patients with CC due to the congenital elongation of the sigmoid colon at early stages of the disease allows predicting the course of the disease and choosing optimal patient treatment tactics. Normalization of sIgA levels in the coprofiltrate during the subcompensated stage indicates the exhaustion of compensatory mechanisms of the child's body and this fact should be considered at stages as a marginal indicator of the onset of decompensation.

\section{CONCLUSIONS}

Chronic constipation in children against the background of CESC, is accompanied by changes in the microbiocenosis of the large intestine lumen and tissue immunity, reflecting the stages in $94.5 \%$.

The choice of efficient conservative therapy in children with dolichosigmoid should be based on the results of a comprehensive examination of patients, which must include microbiological, biochemical analysis of faeces, as well as finding the level of secretory immunoglobulin A in coprofiltrates.

Children with CESC show a decrease in sIg A levels in coprofiltrates by 1.3, decrease in Lysozyme levels in coprofiltrates by 1.24 times as compared to the generally healthy children, which indicates the deficiency of mucosal immunity and contributes to the persistence and development of dysbiotic disorders in the bowels, progression of decompensation, and is directly and closely connected with the severity of constipation in children with CESC.

\section{SUMMARY}

CC for children on a background dolichosigmoid, in $94.5 \%$ accompanied by the changes of microbiocenosis of colon and local immunity, that represent the stages of motion. To our opinion children have a choice of effective conservative therapy on a background dolichosigmoid, must be based on the results of complex inspection of patients, that must include the microbiological, biochemical analysis of excrement, and also determination of level of secretory immunoglobulin A and Lysozyme levels in coprofiltrats.

\section{REFERENCES}

1. Бєлоусова О.Ю., Казарян Л.В. Функціональні гастроінтестинальні розлади в дітей раннього віку: лікувати, спостерігати чи корегувати? Здоров'я дитини. 2020. Т. 15, №. 1. C. 24-29. DOI: 10.22141/2224-0551.15.1.2020.196754. 
2. Боднар Г.Б., Боднар Б.М. Принцип FР в корекції дисинхронозу моторноевакуаторної функції кишечника в дітей. Здоров'я дитини. 2019. T. 14. № 1. C. 48-52. DOI: 10.22141/2224-0551.14.0.2019.165519.

3. Николаева С.В., Горелов А.В. Лечение и профилактика функциональных запоров у детей. Трудный пащиент. 2019. Т. 17. № 1-2. С. 37-41.

4. Borowitz S.M., Cox D.J. Treatment of childhood constipation by primary care physicians: efficacy and predictors of outcome. Pediatrics. 2005. Vol. 115. № 4. P:873-877. DOI: 10.1542/peds.2004-0537.

5. Risk factors for chronic constipation based on a general practice sample / N.J. Talley et al. Am J Gastroenterol. 2003. Vol. 98, № 5. P. 1107-1111. DOI: 10.1111/j.1572-0241.2003.07465.x.

\section{Information about authors: \\ Bodnar G. B., \\ Professor, MD,}

Professor of the Department of Pediatrics and Medical Genetics

Higher State Educational Establishment of Ukraine

"Bukovinian State Medical University"

36/1, O. Gonchara str., Chernivtsi, 58001, Ukraine

Bodnar B. M.,

Professor, MD,

Professor of the Department of Pediatric Surgery and ENT Diseases Higher State Educational Establishment of Ukraine "Bukovinian State Medical University" 36/1, O. Gonchara str., Chernivtsi, 58001, Ukraine 